Supporting information

\title{
Simple means for fractionating protein based on isoelectric point without ampholyte
}

Huang Chen, Zaifang Zhu, Haiqing Yu, Joann Juan Lu, and Shaorong Liu*

Department of Chemistry and Biochemistry, University of Oklahoma, 101 Stephenson Parkway, Norman, Oklahoma 73019, United States

SI includes:

1. Preparation of protein complex from Hela cell mitochondria

2. Effect of Pharmalyte on MS signal

3. MALDI-TOF-MS analysis of fractionated protein

4. Detailed construction of DMI

Corresponding author:

Shaorong Liu

Department of Chemistry and Biochemistry

University of Oklahoma

101 Stephenson Parkway, Norman, OK 73019, USA

Email: Shaorong.liu@,ou.edu

Fax: 4053256111 


\section{Preparation of protein complex from Hela cell mitochondria}

Approximately $6^{*} 10^{7}$ cells were harvested and then washed with PBS three times at $1000 \mathrm{rpm}$ for 5 min each time after trypsinization. Cells suspended in PBS were broken by sonication as described in the manuscript text. All cell debris and nuclei were removed by centrifugation at $1000 \mathrm{x} \mathrm{g}$ for $10 \mathrm{~min}$ at $4{ }^{\circ} \mathrm{C}$. Mitochondria was collected from the supernatant by centrifuging at $12,000 \mathrm{x}$ g for $20 \mathrm{~min}$ at $4{ }^{\circ} \mathrm{C}$ and washed once with PBS buffer. The obtained mitochondrial pellets can be stored at $-80{ }^{\circ} \mathrm{C}$ for future use or suspended by adding $250 \mu \mathrm{L}$ of sample buffer containing $1 \% \mathrm{w} / \mathrm{v}$ lauryl maltoside, $250 \mathrm{mM}$ sucrose, $10 \mathrm{mM}$ HEPES, and $1 \mathrm{mM}$ EDTA (pH 7.0) for immediate use. The sample was layered on the top of a stepwise density gradient of sucrose, which was prepared by orderly adding $300 \mu \mathrm{L}$ each of $43,40,37.5,35,32.5,30,27.5$, $25,22.5,20,17.5,15,10 \%$ in $10 \mathrm{mM}$ HEPES and $0.05 \% \mathrm{w} / \mathrm{v}$ lauryl maltoside $\mathrm{pH} 7.0$ onto an Ultra-Clear $^{\mathrm{TM}}$ centrifuge tube (Beckman Coulter, Inc., CA). The ultracentrifugation proceeded for $20 \mathrm{~h}$ at $40000 \mathrm{rpm}$ in the MLS-50 swing-bucket rotor of Beckman Optima ${ }^{\mathrm{TM}} \mathrm{MAX}-\mathrm{XP}$ machine (Beckman Coulter, Inc.). The protein complex from mitochondria was aspirated out from centrifuge tube.

\section{Effect of Pharmalyte on MS signal}

To examine the effect of additives on MS signal, we mixed Pharmalyte at various concentrations with Trypsinogen, and loaded this solution $(\sim 0.5 \mu \mathrm{L}$ per spot) directly onto a MALDI-MS target plate. After the solvent was dried, we added $0.5 \mu \mathrm{L}$ of MALDI-MS matrix, a 1:1 mixture of solution A and solution B (A: $20 \mathrm{mg} / \mathrm{mL} \alpha$-cyano-4-hydroxycinnamic acid, 50\% ACN and 50\% Methonal; B: $30 \% \mathrm{ACN}$ and $0.1 \%$ Trifluoroacetic acid) to each sample spot and allowed the sample to evaporate again. Figure $2 \mathrm{~s}$ exhibits the effect of Pharmalyte on the MS signal. Figure 
2B, 2C and 2D show that Pharmalyte severely suppressed the MS signal. At 3.6\% Pharmalyte, no MS signal could be detected. Even at $0.9 \%$ Pharmalyte, the MS signal was reduced by 17 fold relative to the MS signal of the protein in $10 \mathrm{mM}$ ammonium acetate buffer.
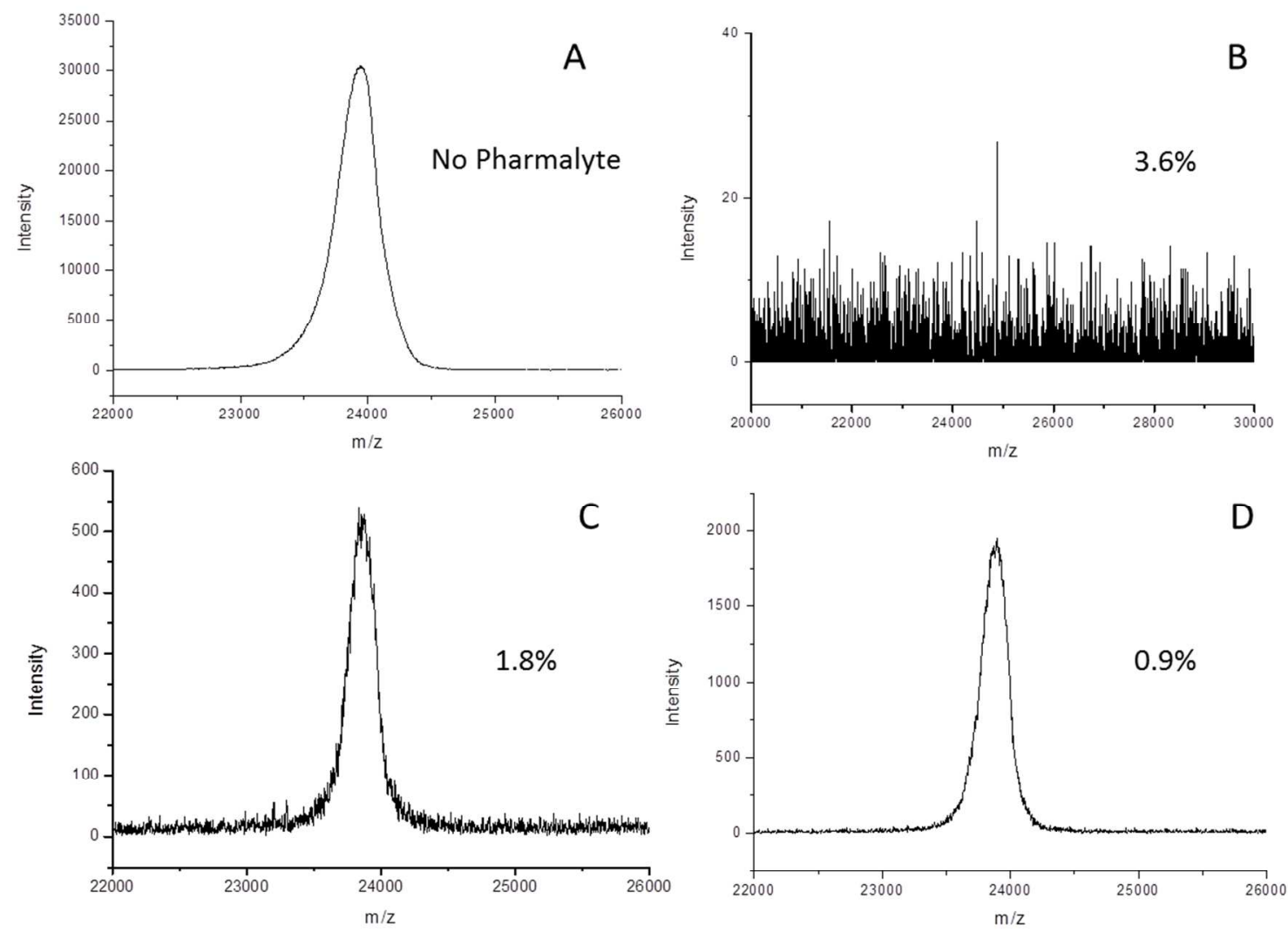

Figure S1. Effect of Pharmalyte on MS signal. The sample contained $0.2 \mu \mathrm{g} / \mu \mathrm{L}$ Trypsinogen and various concentrations of Pharmalyte. $0.5 \mu \mathrm{L}$ of this sample was loaded a MALDI target plate. After the sample was dried, $0.5 \mu \mathrm{L}$ of a matrix solution was added to the sample spot. Then the matrix solvent was evaporated and the target plate was loaded into an Applied Biosystems 4800 Proteomics Analyzer. The MS spectra were measured at an $\mathrm{m} / \mathrm{z}$ range of $15 \mathrm{kDa}-30 \mathrm{kDa}$ with a focus $\mathrm{m} / \mathrm{z}$ of $24 \mathrm{kDa}$ in a linear mode. Spectra in Figures S1B, S1C and S1D were obtained from the protein-Pharmalyte mixtures, while spectra in Figures S1A were obtained from the protein in $10 \mathrm{mM}$ ammonium acetate buffer.

\section{MALDI-TOF-MS analysis of fractionated protein}

A commercial MALDI-TOF-MS (model 4800 plus, AB Sciex, Darmstadt, Germany) was used for mass analysis of fractionated protein complex sample. Positively charged ions were analyzed 
in the linear mode. Two basic matrixes (matrix A containing $10 \mathrm{mg} / \mathrm{mL} \mathrm{CHCA}$ in $70 \% \mathrm{v} / \mathrm{v}$ acetonitrile-water with $5 \% \mathrm{v} / \mathrm{v}$ formic acid; Matrix B containing $10 \mathrm{mg} / \mathrm{mL}$ DHB in $70 \% \mathrm{v} / \mathrm{v}$ acetonitrile-water with $0.05 \% \mathrm{v} / \mathrm{v}$ trifluoroacetic acid) were 1:1 mixed right before use. The above mixture was then mixed with a sample at a 1:1 ratio. The sample-matrix mixture was then loaded onto a metal target plate. Mass spectra of intact proteins was obtained by averaging 1000 random laser shots on each sample spot.

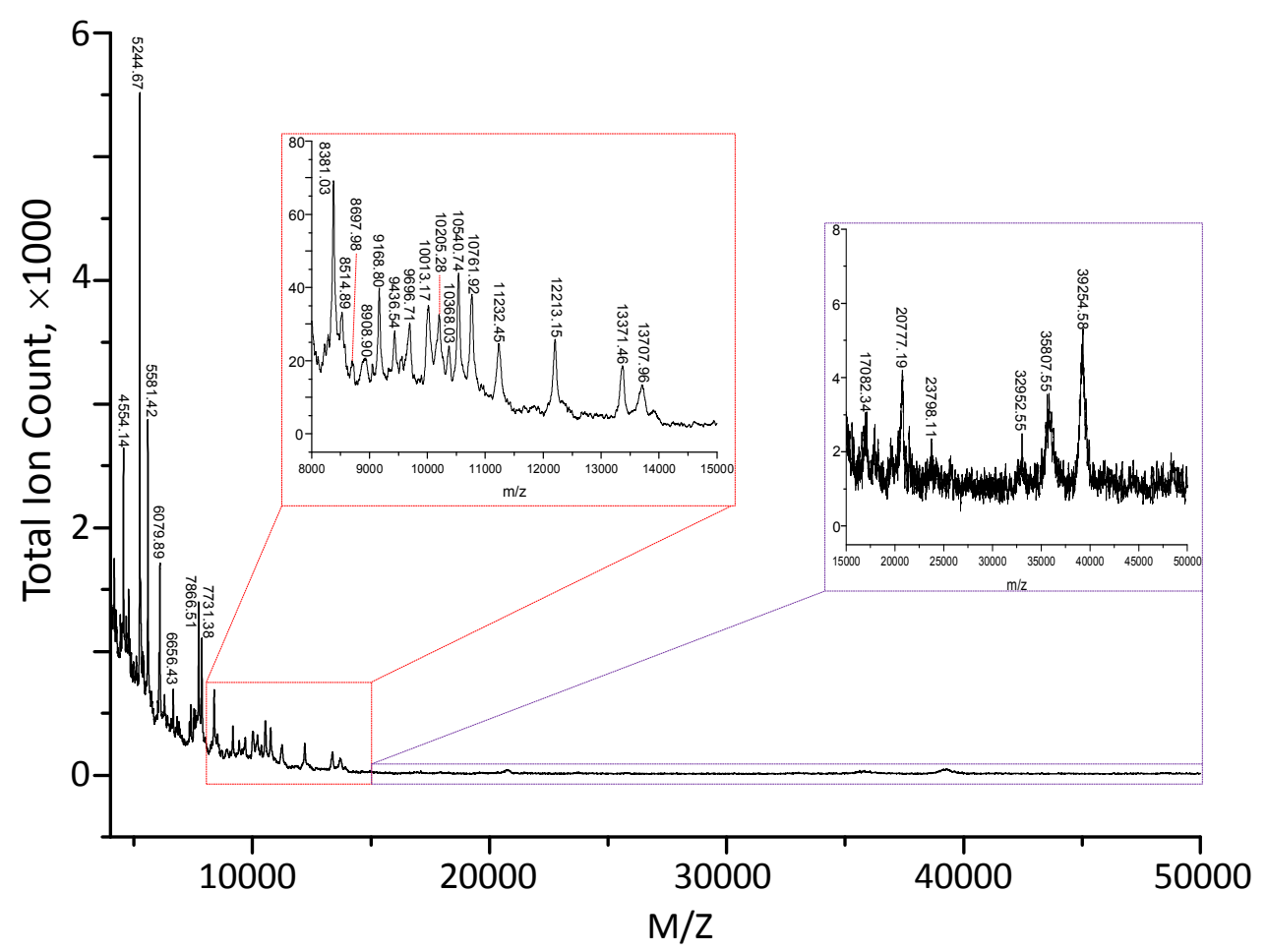

Figure S2. MALDI-TOF MS of Intact proteins from fractionated mitochondrial complexes. 

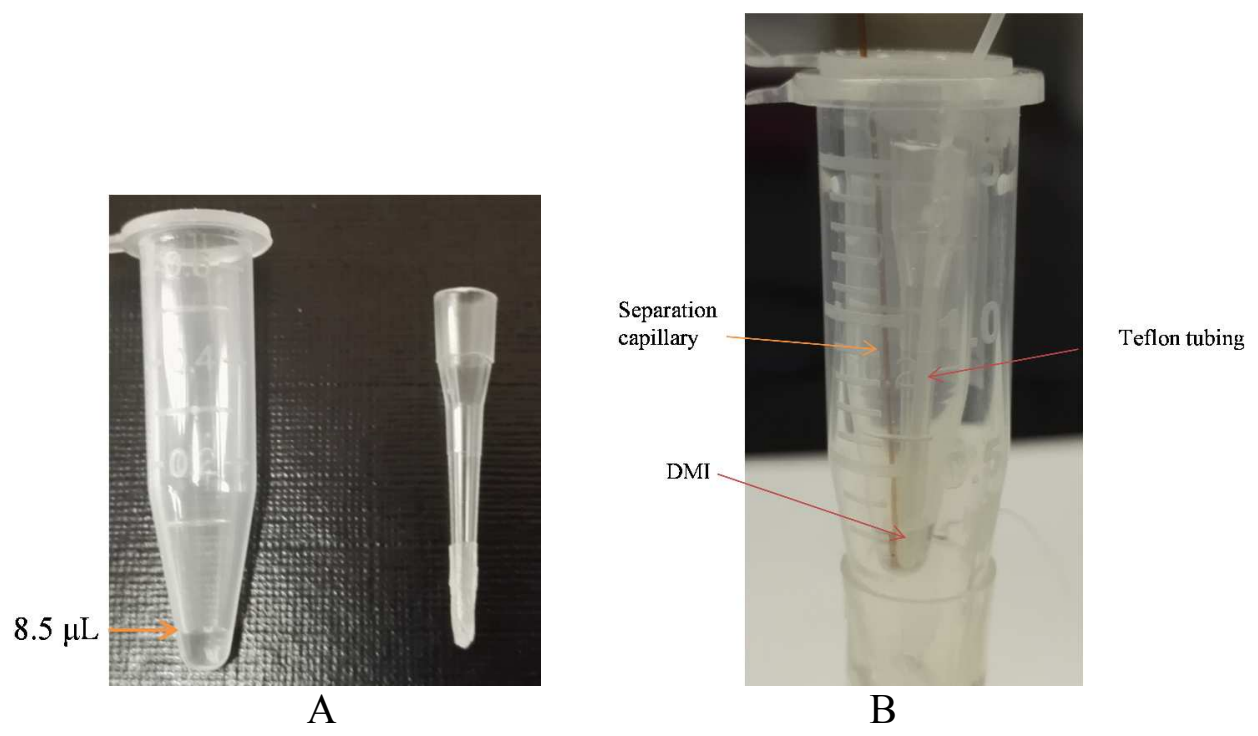

Figure S3. Detailed construction of DMI. A) $0.6-\mathrm{mL}$ vial (left) with $8.5 \mu \mathrm{L}$ solution in it and dialysis membrane tip (right). B) DMI assembly. After the dialysis membrane tip was loaded with some buffer, a Teflon tubing filled with the same buffer solution was used for electrical connection. The above membrane tip and an end of a separation capillary were dipped into the $8.5-\mu \mathrm{L}$ solution inside the $0.6-\mathrm{mL}$ vial. (Note: the DMI assembly was put inside a $2-\mathrm{mL}$ vial when the picture was taken.) 